Asian Journal of Pharmaceutical Research and Development

\author{
Open Access to Pharmaceutical and Medical Research
}

$\mathbf{R}$

Open Access to Pharmaceutical and Medical Research

(C) 2013-18, publisher and licensee AJPRD, This is an Open Access article which permits unrestricted non-commercial use, provided the original work is properly cited

\title{
Original Article \\ Screening of Selected Sri Lankan Seasonal Fruit Extracts for Total Antioxidant Activity in Vitro
}

\section{Amarosige Shanoli Kavindya Fernando ${ }^{1}$, Anoja Priyadarshani Attanayake ${ }^{\star 2}$, Kamani Ayoma Perera Wijewardena Jayatilaka ${ }^{2}$}

${ }^{1}$ Department of Medical Laboratory Sciences, Faculty of Allied Health Sciences, University of Ruhuna, Galle, Sri Lanka. ${ }^{2}$ Department of Biochemistry, Faculty of Medicine, University of Ruhuna, Galle, Sri Lanka.

\begin{abstract}
A B S T R A C T
The present study aimed to determine the total polyphenol content and total antioxidant activities of ten selected seasonal fruit extracts grown in Sri Lanka. The aqueous refluxed fruit extracts (4h) were used at the initial concentration of $0.05 \mathrm{~g} / \mathrm{mL}$. The total polyphenol content was determined according to the Folin-Ciocalteu method. The total antioxidant activity was evaluated by DPPH (2, 2-diphenyl-2-picrylhydrazyl), FRAP (ferric reducing power) and TBA (thiobabituric acid assay) assays with L-ascorbic acid as the reference compound. The total polyphenol content of the fruit extracts varied from $0.81 \pm 0$ to $17.54 \pm 0.50 \mathrm{mg} \mathrm{GAE}$ (gallic acid equivalents) per gram of dry weight. The antioxidant activities ranged in $\mathrm{IC}_{50}$ of $46.60 \pm 0.60$ to $367.90 \pm 4.90 \mu \mathrm{g} / \mathrm{mL}, 3.41 \pm 0.02$ to $50.46 \pm 1.02 \mu \mathrm{M}, 30.62 \pm 0.50$ to $182.64 \pm 0.90 \mathrm{mg}$ AAE (L-ascorbic acid equivalents) per gram of dry weight for DPPH, FRAP, TBA assays, respectively. All aqueous fruit extracts exert dose dependent in vitro antioxidant activities in different degrees. Among the selected fruit extracts S. carophylatum, P. zeylanica, A. comosus exert relatively high total antioxidant activity together with high total polyphenol content. Hence, the selected fruit extracts are deserved to be as potent sources for antioxidant lead compounds in the development of nutraceuticals using the above edible fruits
\end{abstract}

Key words: Antioxidant assays, FRAP assay, DPPH assay, nutraceuticals, Sri Lankan fruit extracts, TBA assay

A R T I C L E I N F O: Received: 23 Nov. 2018; Review Completed: 20 Dec.2018; Accepted: 5 Feb .2019; Available online: 15 Feb. 2019

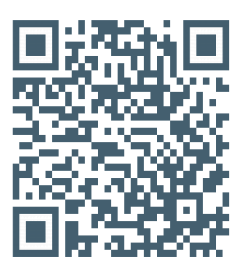

Cite this article as:

Amarosige Shanoli Kavindya Fernando, Anoja Priyadarshani Attanayake and Kamani Ayoma Perera

Wijewardena Jayatilaka, Screening of Selected Sri Lankan Seasonal Fruit Extracts for Total Antioxidant

Activity in vitro, Asian Journal of Pharmaceutical Research and Development. 2019; 7(1):07-12

DOI: http://dx.doi.org/10.22270/ajprd.v7i1.459

*Address for Correspondence

Anoja Priyadarshani Attanayake, Department of Biochemistry Faculty of Medicine,University of Ruhuna Galle, Sri Lanka

\section{INTRODUCTION}

$\mathrm{F}$ Truits as plant based food have been deserved a particular interest over the last two decades. In fact, fruits possess a multitude of health benefits, widely known since pre-historic era. Notwithstanding, due to the absence of scientific validation, awareness on nutritional benefits, fruits were poorly consumed by general public, and/or recommended as dietary supplements for different disease conditions. In recent years, it is evident that the consumption of plant based foods is related to reduction in mortality in several oxidative stress related diseases, including mortality from cardio vascular disease and cancer ${ }^{1}$. This may be due in part to the high amounts of beneficial components present in plant food such as dietary fiber, folate, antioxidants, vitamins, polyphenols, and potassium, which are associated with lower risk of cardio vascular disease. Accordingly, five daily portions of fruits and vegetables (approximately $400 \mathrm{~g} /$ day) have been recommended as part of a public health strategy for the prevention of chronic diseases ${ }^{2}$.
Medical and nutritional research has for decades, emphasized the health benefits of consuming fruits and their role in the management/ prevention of chronic diseases/conditions such as cardiovascular disease, certain cancers, type II diabetes mellitus, obesity, chronic kidney disease, chronic lung disease, chronic obstructive pulmonary disease etc ${ }^{3}$. Further, the World Health Organization estimation data has revealed that, approximately 1.7 million (2.8\%) deaths from diet related chronic diseases per annum are linked with low consumption of fruits and vegetables ${ }^{2}$.The importance of consumption of fruits and their involvement in the protection of cells from oxidative stress has become a debatable topic in this era ${ }^{4}$. In particular, phytochemicals with antioxidant potential are wellreported to play a role in reducing the consequences of oxidative stress in disease development and in aging process, thus contribute to overall health-protective effects 5 .

Antioxidants are molecules which are capable of delaying or inhibiting the action of free radicals. Indeed, 
antioxidants from exogenous sources are considered as important in such oxidative stress conditions, in order to prevent or slow down the oxidative stress induced by excessive production of free radicals ${ }^{6}$. Although there are synthetic antioxidants, certain physical properties related to these such as high volatility, instability and carcinogenicity have shifted scientists' attention to isolate natural antioxidants specifically from plant origin 7. Accordingly, fruits contain a wide variety of phytochemicals that may help to protect cellular systems from oxidative damage and to reduce the occurrence of chronic diseases ${ }^{8}$. Among the identified phytochemicals, polyphenolic compounds including tannins and flavonoids are important groups of antioxidants targeting nutritional and medicinal applications ${ }^{9}$.

Fruits are considered as important components of the Sri Lankan diet for decades. Recent study shows that, there is an upward trend in the consumption of fruits by Sri Lankans for the past 30 years ${ }^{10}$. With consideration of the great value of fruits as dietary sources of antioxidants and development of nutraceuticals with potent antioxidant potentials for patients with oxidative stress related diseases, the determination of antioxidant activity and identification of related antioxidants/ phytochemicals of fruits seems an important area of ethno-pharmacology research. Fruits have historically held a place in dietary guidance because of their concentrations of vitamins, especially vitamins $\mathrm{C}$ and $\mathrm{A}$; minerals, especially electrolytes; and more recently phytochemicals, especially antioxidants.

However, many of the Sri Lankan fruit extracts have not been subjected to determine the antioxidant activity. Despite the evidence put forward by studies in the recent past, there is still a need for the determination of total antioxidant activities of seasonal fruit extracts of Sri Lankan origin. The selected fruits for the investigation are as follows. Durian- Durio zibethinusn L. (Bombacaceae), Pineapple- Ananas comosus L. Merr. (Bromeliaceae), Namnam- Cynometra cauliflora L. (Fabaceae), Santol- Sadoricum koefjape L. (Meliaceae), Heen dan- Syzygium caryophyllatum L. Alston (Myrtaceae), Whild date palm- Phoenix zeylanica L. (Palmae), Strawberry- Fragaria vesca L. (Rosaceae), Rambutan- Nephelium lappaceum L. (Sapindaceae), Kirala- Sonneratia alba Sm. (Sonneratiaceae) and Grapes- Vitis venefera (Vitaceae). The objectives of the present study were to determine the total polyphenol content of the selected aqueous fruit extracts of Sri Lankan origin and to determine the total antioxidant activities of the aqueous fruit extracts using standard assay methods.

\section{MATERIALS AND METHODS}

\section{Chemicals and reagents}

All chemicals and solvents were of analytical grade and were used without any purification.

\section{Instruments}

A UV visible spectrophotometer (Gallenkamp PLC, UK) and a $\mathrm{pH}$ meter (EUTEC, Singapore) were used for spectrophotometric measurements and for the measurement of $\mathrm{pH}$ respectively.

\section{Collection and identification of fruits}

The selected fruits were collected from Galle, Deniyaya, Negombo, Kalpitiya and from Jaffna, Sri Lanka during July to September 2016. The botanical identification of the fruits/plants was done with the use of description given by Jayaweera, $1982^{11}$.

\section{Preparation of fruit extract}

Aqueous refluxed extracts of fruits were used in experiments. The edible fruit part $(100 \mathrm{~g})$ was oven dried at $40^{\circ} \mathrm{C}$ to a constant weight and ground to obtain the dried powder. Powdered fruit material (5.0 g) was dissolved in $400 \mathrm{~mL}$ distilled water and refluxed for 4 $\mathrm{hr}$. The mixture was strained and the final volume was adjusted to $100.0 \mathrm{~mL}$. The initial concentration of each of the fruit extract was $0.05 \mathrm{~g} / \mathrm{mL}$. A graded series of dilutions was prepared $(1-500 \mu \mathrm{g} / \mathrm{mL})$ for the $\mathrm{DPPH}$ assay.

\section{Estimation of total polyphenol content}

Total polyphenol content was estimated using Folinciocalteu method using gallic acid as the reference compound ${ }^{12}$. Briefly, fruit extract $(1.0 \mathrm{~mL})$ was mixed with $95 \% \mathrm{EtOH}(1.0 \mathrm{~mL})$, distilled water $(5.0 \mathrm{~mL})$ and of $50 \%$ Folin-Ciocalteu $(0.5 \mathrm{~mL})$ reagent. The mixture was allowed to react for $5 \mathrm{~min}$ and $5 \% \mathrm{Na}_{2} \mathrm{CO}_{3}(1.0 \mathrm{~mL})$ was added. Thereafter, it was thoroughly mixed and placed in dark at room temperature $\left(25^{\circ} \mathrm{C}\right)$ for $1 \mathrm{hr}$ and the absorbance was measured spectrophotometrically at $725 \mathrm{~nm}$. Quantification was done with respect to the standard curve of gallic acid $(0-50 \mu \mathrm{g} / \mathrm{mL})$. The results were expressed in $\mathrm{mg}$ gallic acid equivalents $\mathrm{mg} \mathrm{GAE} / \mathrm{g}$ of the dry weight.

\section{Determination of total antioxidant activity}

\section{2, 2'-diphenyl-2-picrylhydrazyl hydrate (DPPH) radical scavenging assay method}

Total antioxidant activity was measured by DPPH radical scavenging assay method ${ }^{13}$. EtOH was used as the sample blank. A graded series of a concentration (1$500 \mu \mathrm{g} / \mathrm{mL})$ of fruit extract $(1.0 \mathrm{~mL})$ were added to $0.004 \%$ ethanol DPPH $(3.0 \mathrm{~mL})$ solution. The mixture was shaken vigorously, allowed to stand at $25^{\circ} \mathrm{C}$ in dark for $30 \mathrm{~min}$. The decrease in absorbance of the resultant solution was measured spectrophotometrically at the same wave length $\left(\mathrm{A}_{\text {sample }}\right)$. L-Ascorbic acid was used as the reference compound. The antioxidant activity is expressed in terms of $\mathrm{IC}_{50}$ (concentration of the extract /reference compound required to inhibit DPPH radical formation by $50 \%)$. \% DPPH radical scavenging activity $=\left(\mathrm{A}_{\text {control}}-\mathrm{A}_{\text {sample }}\right) / \mathrm{A}_{\text {control }} \mathrm{x} 100 \%$ where, $\mathrm{A}_{\text {control }}$ represents the absorbance of the control without the plant/ reference compound.

\section{Ferric reducing antioxidant potential (FRAP) assay}

FRAP assay was used as described by Benzie and Strain, $1999^{14}$. The FRAP working reagent was prepared by mixing acetate buffer ( $300 \mathrm{mM}, \mathrm{pH} 3.6)$, a solution of 10 $\mathrm{mM}$ TPTZ in $40 \mathrm{mM} \mathrm{HCl}$ and $20 \mathrm{mM} \mathrm{FeCl}_{3}$ at 10:1:1 $(\mathrm{v} / \mathrm{v} / \mathrm{v})$. The FRAP reagent $(3.0 \mathrm{~mL})$ and sample solution 
$(100 \mu \mathrm{L})$ were mixed and the absorbance of the resulting solution was measured $(\mathrm{t}=0)$ at $593 \mathrm{~nm}$ spectrophotometrically ( $A_{\text {sample }} \mathrm{t}=0$ ) against a sample blank (FRAP working reagent).

Thereafter the sample was placed in a water bath $\left(37^{\circ} \mathrm{C}\right)$ and the absorption was measured at the same wave length after $4 \mathrm{~min}$. $\left(\mathrm{A}_{\text {sample }} \mathrm{t}=4\right)$. L-ascorbic acid (1000 $\mu \mathrm{M}$ ) was used as the standard compound and preceded as in the same way.

FRAP value of the plant extract $(\mu \mathrm{M})=\left(\mathrm{A}_{\text {sample }} \mathrm{t}=0\right.$ 4)/ $\left.\mathrm{A}_{\text {standard }} \mathrm{t}=0-4\right) \times$ FRAP value of $1000 \mu \mathrm{M}$ ascorbic acid.

where, $\left(\mathrm{A}_{\text {sample }} \mathrm{t}=0-4\right)$ represents the change in absorbance in a sample from 0 to $4 \mathrm{~min},\left(\mathrm{~A}_{\text {standard }} \mathrm{t}=0-4\right)$ is the change in absorbance in the standard from 0 to 4 min. FRAP value of ascorbic acid is 2 .

\section{Thiobabituric acid assay (TBA)}

TBA assay was performed as described by Ottolenghi, $1959{ }^{15}$. Briefly, $20 \%$ trichloroacetic acid $(2.0 \mathrm{~mL})$ was mixed with $0.67 \%$ thiobabituric acid $(2.0 \mathrm{~mL})$ and sample solution $(1.0 \mathrm{~mL})$ was added to the above acidic media. This mixture was boiled (1000C) in a water bath for10 min. It was allowed to cool and filtered. The absorbance of the sample was measured at $552 \mathrm{~nm}$ using a water blank. L-ascorbic acid $(100-500 \mu \mathrm{g} / \mathrm{mL})$ was used as the reference compound. The results were expressed in ascorbic acid equivalents $\mathrm{mg} \mathrm{AAE} / \mathrm{g}$ of the dry weight.

\section{Phytochemical screening of fruits}

Preliminary qualitative phytochemical screening for the presence of saponins(a), cardenolide glycosides(b), phenols(c), alkaloids (d), flavonoids (e), tannins(f), reducing sugars $(\mathrm{g})$, and proteins $(\mathrm{h})$ was carried out by the reported protocol ${ }^{16}$.

\section{Statistical data analysis}

The triplicates of each sample were used for statistical analysis and the values were expressed as mean \pm standard deviation.

\section{RESULTS AND DISCUSSION}

The present study was carried out to determine the total polyphenol content and antioxidant activity of selected fruit extracts using standard assay methods. The selection of fruits for the investigation was mainly based on the availability of them during the period of July to September of the year. Most of the fruits selected for the investigation are widely consumed by the general public in the selected areas. Some of the selected fruits also have been used as a dietary supplement for the management of a number of oxidative stress related chronic disease conditions. Examples include $A$. comosus juice is used for the management of diarrhoea and jaundice, $S$. carophylatum is prescribed for diabetes mellitus, $V$. venefera is useful for cough etc. ${ }^{11}$. The antioxidant potential of the most of the fruit extracts is documented in literature however, it has not scientifically proven up to date.

is measured at ambient temperature, therefore that the risk of thermal degradation of the molecules tested is
In the present study, the total polyphenol content of the fruit extracts was determined by classical FolinCiocalteu reagent method. Three well established antioxidant assay methods were selected to determine total antioxidant activities accordingly DPPH (2, 2diphenyl-2-picrylhydrazyl hydrate) radical scavenging assay, FRAP (ferric reducing power) assay, and TBA (Thiobarbituric assay) assay, considering the wide diversity in the antioxidants' chemical structure ${ }^{9}$. In addition this may optimize the antioxidant properties of a single fruit extract to a maximum possible extent.

Polyphenols are considered as a group of secondary metabolites that are mostly related to the antioxidant activity. In addition, polyphenolic compounds (including tannins and flavonoids) are the most important groups of exogenous antioxidants that have been used as nutritional and medicinal therapeutics. Polyphenols react with an oxidizing agent phosphomolybdate in FolinCiocalteu reagent under alkaline conditions and result in the formation of a blue coloured complex, the molybdenum blue which is measured at $650 \mathrm{~nm}$ spectrophotometrically. The total polyphenolic content of the selected aqueous fruit extracts were calculated by using regression analysis of gallic acid standard curve $(y=0.01017 x+0.004810)$ and the total polyphenol values of the fruit extracts were ranged from $0.81 \pm 0$ to $17.54 \pm 0.50 \mathrm{mg} \mathrm{GAE} / \mathrm{g}$. The highest and the lowest total polyphenol content were shown in the fruit extracts of $S$. caryophyllatum and $S$. koefjape respectively. The total polyphenol content was increased in the ascending order of extracts of $S$. alba, $P$. zeylanica, $V$. venefera, $F$. vesca, $S$. caryophyllatum as shown in Table 1. The polyphenol content of most of the reported fruit extracts were comparable with the results obtained in the present investigation. As examples, the extracts of Dialium guineense (Leguminosae, velvet tamarind), Flacourtia inermis (Flacourtiaceae, Lovi), Phyllanthus emblica (Euphorbiaceae, Nelli) the total polyphenol content was in a range of 0.77 to $12.8 \mathrm{mg} \mathrm{GAE} / \mathrm{g} 17,18,19$ as the results of this study is ranged within 0.8 to $17.5 \mathrm{mg}$ $\mathrm{GAE} / \mathrm{g}$.

It's a well-known fact that antioxidant activity varies according to the extraction method and on the solvent used for the extraction because of the presence of various antioxidant compounds with different chemical characteristics and polarities may or may not be soluble in a particular solvent 9. However, in the present study, water extracts were used since the water extracts are more nutritionally and medicinally relevant for human consumption ${ }^{20}$. Indeed, the aqueous extracts are more relevant and are being able to simulate the way of consumption since fruits are eaten in raw or used as fresh juice. In this study fruit extracts were refluxed for four hours for the maximum extraction of active phytochemicals to the relevant extract ${ }^{21}$.

DPPH assay method is the most widely mentioned radical scavenging assay method to determine the antioxidant activities in most available recent research. It is an accurate, easy, rapid and simple method to evaluate antioxidant activity in vitro. The antioxidant efficiency

eliminated. The advantage of this method is that DPPH is allowed to react with the whole sample and sufficient 
time is given in the method which allows DPPH to react slowly even with weak free radical scavengers ${ }^{21}$. However, it has some limitations due to DPPH radical interaction with other radicals and the time response curve to reach the steady state is not linear with different ratios of antioxidant/DPPH ${ }^{13}$. The results of the present investigation demonstrated that the selected fruit extracts exert relatively high antioxidant activity as evident by the values of $\mathrm{IC}_{50}$ in DPPH assay $(46.60 \pm 0.60$ to 367.90 $\pm 4.90 \mu \mathrm{g} / \mathrm{mL}$ ). However, the $\mathrm{IC}_{50}$ values estimated for DPPH assay in the study is not comparable mostly with the previously published reports. As example Caryota urens (Arecaceae, Kithul) $\mathrm{IC}_{50}$ ranged from 6.02 to 3.73 $\mu \mathrm{g} / \mathrm{mL}{ }^{22}$ and for Punica granatum $L$ (Punicaceae, Delum) $\mathrm{IC}_{50}$ is $0.182 \mathrm{mg} / \mathrm{mL}^{23,24}$. The differences in $\mathrm{IC}_{50}$ values may due to the differences between methods of extraction, time of extraction, regions where the fruits were collected. In this study, L-ascorbic acid was used as the reference compound and showed the lowest $\mathrm{IC}_{50}$ value thus the highest antioxidant activity. Folin Ciocalteu method can be interfered by other oxidation substrate in a given extract in an inhibitory, additive or enhancing manner. All extracts and standard compounds exhibited concentration dependent radical scavenging activities in DPPH assay and it was ranged from $\mathrm{IC}_{50}$ values of $46.60 \pm 0.60$ to $367.90 \pm 4.90 \mu \mathrm{g} / \mathrm{mL}$. $P$. zeylanica has the lowest $\mathrm{IC}_{50}$ value expressing the highest radical scavenging activity. S. koefjape has the highest $\mathrm{IC}_{50}$ value expressing the lowest radical scavenging activity in the ascending order of $S$. alba, $D$. zibethinus, S. caryophyllatum, A. comosus, $P$. zeylanica (Table 1).

The FRAP assay is inexpensive and reagents are simple to prepare. The results are highly reproducible, and the procedure is straightforward and relatively speedy. FRAP values are obtained by comparing the change of absorbance at $593 \mathrm{~nm}$ in test reaction mixtures with those containing ferrous ions in known concentration ${ }^{14}$. Changes in the absorption are linear over a wide concentration range of natural extracts. Reducing power of each fruit extract is expressed as FRAP value which is ranged from $3.41 \pm 0.02$ to $50.46 \pm 1.02 \mu \mathrm{M}$ as shown in Table 1 .

Table 1: Total polyphenol content and antioxidant activity of ten selected fruit extracts

\begin{tabular}{|c|c|c|c|c|}
\hline Fruit extract & $\begin{array}{l}\text { Total Polyphenol } \\
\text { content } \\
\text { (mgGAE/g DW) }\end{array}$ & $\begin{array}{l}\text { DPPH radical } \\
\text { scavenging assay } \mathrm{IC}_{50} \\
(\mu \mathrm{g} / \mathrm{mL} \mathrm{IC50}\end{array}$ & $\begin{array}{l}\text { FRAP assay } \\
\text { FRAP value }(\mu M)\end{array}$ & $\begin{array}{l}\text { TBA assay } \\
\text { (AAE/gDW) }\end{array}$ \\
\hline D. zibethinus & $1.46 \pm 0$ & $116.7 \pm 1.3$ & $3.5 \pm 0.04$ & $30.6 \pm 0.5$ \\
\hline A. comosus & $2.48 \pm 0.12$ & $87.8 \pm 0.6$ & $4.7 \pm 0.04$ & $133.4 \pm 0.5$ \\
\hline C.cauliflora & $1.30 \pm 0.10$ & $328.0 \pm 9.0$ & $24.4 \pm 2.05$ & $42.0 \pm 0.6$ \\
\hline S. koefjape & $0.81 \pm 0$ & $367.9 \pm 4.9$ & $4.6 \pm 0.03$ & $114.8 \pm 1.1$ \\
\hline S. caryophyllatum & $17.54 \pm 0.50$ & $98.2 \pm 1.1$ & $50.5 \pm 1.02$ & $104.3 \pm 0.5$ \\
\hline P. zeylanica & $3.07 \pm 0.20$ & $46.6 \pm 0.6$ & $33.3 \pm 1.02$ & $182.6 \pm 0.9$ \\
\hline F. vesca & $9.181 \pm 0.15$ & $218.4 \pm 13.2$ & $25.0 \pm 0.36$ & $87.9 \pm 0.4$ \\
\hline N. lappaceum & $1.26 \pm 0.01$ & $116.7 \pm 1.2$ & $3.4 \pm 0.02$ & $68.6 \pm 0.2$ \\
\hline S. alba & $2.50 \pm 0.10$ & $142.8 \pm 0.9$ & $29.2 \pm 0.58$ & $58.9 \pm 0.1$ \\
\hline V. venefera & $8.46 \pm 0.10$ & $192.5 \pm 0.6$ & $22.9 \pm 0.00$ & $72.2 \pm 0.5$ \\
\hline
\end{tabular}

All values are the mean of three measurements and expressed as mean \pm SD.

The FRAP value of the fruit extracts in the decreasing order of $S$. caroyphyllatum, P. zeylanica, S. alba, $F$. vesca and $C$. cauliflora. TBA values are ranged from $30.62 \pm 0.50$ to $182.64 \pm 0.90 \mathrm{mg} \mathrm{AAE} / \mathrm{g}$ of dry weight. The highest and the lowest values in the TBA assay in the extracts of $P$. zeylanica and D. zibethinus respectively (Table 1 ). The TBA assay method is an easy and inexpensive method, but the use of TBARS test has received wide criticism over the years. The main problem is the lack of sensitivity and specificity, since TBA reacts with a variety of compounds in medicinal plant extracts ${ }^{15}$.

The phytochemicals present in selected fruit species are mentioned in Table 2. The mentioned phytochemicals mainly polyphenols and flavonoids may be attributed to the total antioxidant activities of the selected fruit extracts. 
Table 2: Phytochemicals present in selected fruit extracts

\begin{tabular}{|l|l|l|l|l|l|l|l|l|}
\hline Fruit extract & $($ a) & (b) & (c) & (d) & (e) & (f) & (g) & (h) \\
\hline D. zibethinus & + & + & + & + & + & + & + & + \\
\hline A. comosus & + & + & + & + & + & + & + & + \\
\hline C.cauliflora & + & - & + & - & + & + & + & + \\
\hline S. koefjape & + & - & + & - & + & + & + & + \\
\hline S. caryophyllatum & + & - & + & - & + & + & + & + \\
\hline P. zeylanica & + & - & + & - & + & + & + & + \\
\hline F. vesca & + & - & + & + & + & + & + & + \\
\hline N. lappaceum & + & - & + & - & + & + & + & + \\
\hline S. alba & + & - & + & - & + & + & + & + \\
\hline V. venefera & + & - & + & - & + & + & + & + \\
\hline
\end{tabular}

Cyanogenic glycosides were not detected. - sign indicates the absence, + sign indicates the presence

\section{CONCLUSIONS}

All aqueous fruit extracts exert in vitro antioxidant activities in different degrees. Among the selected fruit extracts S. carophylatum, P. zeylanica, A. comosus extracts exert relatively high total antioxidant activity together with high total polyphenol content. Hence, the selected fruit extracts are deserved to be as potent sources of antioxidant lead compounds in the development of nutraceuticals using fruits. This is the

\section{REFERENCES}

1. Nicklett EJ, Semba RD, Xue QL, Tian J, Sun K, Cappola AR, Simonsick EM, Ferrucci L, Fried LP. Fruit and vegetable intake, physical activity, and mortality in older community-dwelling women. J Am Geriatr Soc 2012;60(5):862-868.

2. World Health Organization. Promoting fruit and vegetable consumption around the world. Information sheet [Online]. World Health Organization. 2013,

3. http://www.who.int/dietphysicalactivity/fruit/en.

4. Gertsch J. The metabolic plant feedback hypothesis: How plant secondary metabolites nonspecifically impact human health. Planta Med 2016;82(11-12): 920-929.

5. Norat $T$, Aune D, Chan D, Romaguera D. Fruits and vegetables: Updating the epidemiologic evidence for the WCRF/AICR lifestyle recommendations for cancer prevention. Cancer Treat Res 2014; 159:35-50.

6. Oyebode O, Gordon-Dseagu V, Walker A, Mindel, JS. Fruit and vegetable consumption and all-cause, cancer and CVD mortality: Analysis of health survey for England data. J Epidemiol Community Health 2014, ID. 203500.

7. Domej W, Oettl K, Renner W. Oxidative stress and free radicals in COPD - implications and relevance for treatment. Int $\mathrm{J}$ Chron Obstruct Pulmon Dis 2014; 9:1207-1224.

8. Carocho M, Ferreira IC. A review on antioxidants, pro-oxidants and related controversy: Natural and synthetic compounds, screening and analysis methodologies and future perspectives. Food Chem Toxicol 2013; 1: 15-25.

9. Wu SB, Long C, Kennelly EJ. Phytochemistry and health benefits of Jaboticaba, an emerging fruit crop from Brazil. Food Res Int 2013;54(1):148-159.

10. Turkmen N, Sari F and Velioglu SY: Effects of extraction solvents on concentration and antioxidant activity of black and first ever report on the total antioxidant activity of the selected seasonal fruit extracts grown in Sri Lanka.

\section{RESEARCH FUNDING}

The financial assistance by National Research Foundation is greatly appreciated (NSF/RG/2007/HS/10).

\section{CONFLICT OF INTEREST}

Authors declare no conflict of interest.

11. black mate tea polyphenols determined by ferrous tartrate and Folin-Ciocalteu methods. Food Chem 2006;99(4):835-841.

12. Weerahewa J, Rajapakse C, Pushpakumara G. An analysis of consumer demand for fruits in Sri Lanka 1981-2010. Appetite 2013; 60(1): 252-258

13. Jayaweera DMA. Medicinal plants (Indigenous and exotic) used in Ceylon, Part 1-5, National Science Council, Sri Lanka, 1982.

14. Singleton VL, Ortofer R, Lamuda-Raventos RM. Analysis of total polyphenol and other oxidation substances and antioxidants by means of Folin-Ciocalteu regent. Methods Enzymol 1999;29:152178.

15. Brands Williams W, Cuveilier ME, Berset C. Use of a free radical method to evaluate antioxidant activity. LWT Food Sci Technol 1995;28(1): 25-30.

16. Benzei IF, Strain JJ. The ferric reducing ability of plasma (FRAP) as a measure of antioxidant power: The FRAP assay. Anal Biochem 1996;239(1):70-76.

17. Ottolenghi. Interaction of ascorbic acid and mitochondria lipids. Arch Biochem Biophys 2004;79:355-365.

18. Trease GE, Evans WC, Pharmacology. London: Bailliere Tindall Ltd.1978.

19. Alakolanga AGAW, Kumar NS, Jayasinghe L, Fujimoto Y Antioxidant property and $\alpha$-glucosidase, $\alpha$ amylase and lipase inhibiting activities of Flacourtia inermis fruits: Characterization of malic acid as an inhibitor of the enzymes. J Food Sci Technol 2015;52(12):8383-8388.

20. Padmini SM.C, Samarasekara R, Pushpakumara DKNG. Antioxidant capacity and total phenol content of Sri Lankan Annona muricata L. Trop Agric Res 2015;25 (2):252-260.

21. Piyathunga ALI, Mallawaarachchi MALN, Madhujith WMT. Phenolic content and antioxidant capacity of selected underutilized fruits grown in Sri Lanka. Trop Agric Res 2016;27(3):277-286.

22. Møller JKS, Madsen HL, Aaltonen T, Skibsted LH. Dittany (Origanum dictamnus) as a source of water-extractable antioxidants. Food Chem 1999; 64(2):215-219. 
23. Attanayake AP, Jayatilaka KAPW, Pathirana C, Mudduwa L. Phytochemical screening and in vitro antioxidant potentials of extracts of ten medicinal plants used for the treatment of diabetes mellitus in Sri Lanka. Afr J Tradit Complement Altern Med 2015;12(4):28-33.

24. Kedere SB, Singh RP. Genesis and development of DPPH method of antioxidant assay. Food Sci Technol 2011; 48(4): 412-422.
25. Ranasinghe P, Premakumara GAS, Wijayarathna CD Ratnasooriya WD. Antioxidant activity of Caryota urens L. (Kithul) Sap. Trop Agric Res 2015; 24(2):117-125.

26. Bopitiya D, Madhujith T. Antioxidant potential of Pomegranate (Punica granatum L.) cultivars grown in Sri Lanka, Trop Agric Res. 2015; 24(1):71-81. 